\title{
Liquidus temperature and chemical durability of selected glasses to immobilize rare earth oxides waste
}

\author{
Syazwani Mohd Fadzil, ${ }^{\mathrm{a}, b^{*}}$ Pavel Hrma, ${ }^{\mathrm{a}, \mathrm{c}}$ Michael J. Schweiger, ${ }^{\mathrm{c}}$ Brian J. Riley ${ }^{\mathrm{c}}$ \\ ${ }^{a}$ Division of Advanced Nuclear Engineering, Pohang University of Science and Technology, 790784 Pohang, South Korea \\ ${ }^{b}$ The National University of Malaysia, 43650 Bandar Baru Bangi, Selangor, Malaysia \\ ${ }^{c}$ Pacific Northwest National Laboratory, P.O. Box 999, Richland, Washington, United States of America
}

\begin{abstract}
Pyroprocessing is a reprocessing method for managing and reusing used nuclear fuel (UNF) by dissolving it in an electrorefiner with a molten alkali or alkaline earth chloride salt mixture while avoiding wet reprocessing. Pyroprocessing UNF with a $\mathrm{LiCl}-\mathrm{KCl}$ eutectic salt releases the fission products from the fuel and generates a variety of metallic and salt-based species, including rare earth (RE) chlorides. If the RE-chlorides are converted to oxides, borosilicate glass is a prime candidate for their immobilization because of its durability and ability to dissolve almost any RE waste component into the matrix at high loadings. Crystallization that occurs in waste glasses as the waste loading increases may complicate glass processing and affect the product quality. This work compares three types of borosilicate glasses in terms of liquidus temperature $\left(T_{\mathrm{L}}\right)$ : the International Simple Glass designed by the International Working Group, sodium borosilicate glass developed by Korea Hydro and Nuclear Power, and the lanthanide aluminoborosilicate (LABS) glass established in the United States. The LABS glass allows the highest waste loadings (over 50 mass $\% \mathrm{RE}_{2} \mathrm{O}_{3}$ ) while possessing an acceptable chemical durability.
\end{abstract}

Keywords: liquidus temperature, durability, rare earth waste glass, crystallization

\footnotetext{
*Corresponding author: Tel.: +82-54-279-9553; fax: +82-54-279-9559.

E-mail address: mfsyazwani86@postech.ac.kr (S. Mohd Fadzil).
} 


\section{Introduction}

\subsection{Rare earth oxides in pyroprocessing}

To meet energy requirements, the Republic of Korea is planning to construct six nuclear power plants (NPPs) in addition to the five NPPs under construction and 23 NPPs in operation as of December 2012 [1]. However, the accumulated used nuclear fuel (UNF) will reach the maximum capacity of temporary storage facilities by 2016 . This major issue of managing UNF and space requirement needs to be resolved for next-generation safety [2]. One alternative for managing the UNF is using reprocessing technology to reduce the amount of high level waste (HLW) volume in the repository site prior to disposal $[2,3]$. Unlike wet reprocessing technology, such as the plutonium and uranium extraction process, molten salt reprocessing technology, such as pyroprocessing, minimizes the proliferation risk [2] and produces less liquid waste.

Pyroprocessing separates transuranic elements by electrolytic reduction, including uranium from UNF, for reuse as fuel in fast reactors [3,4]. The waste contains rare earth (RE) fission products that are converted to chlorides in the electrorefiner [3-5]. Once these fission products become too concentrated in the electrorefiner, the separations efficiency is negatively impacted. Thus, at that stage, the fission products either need to be selectively removed or the salt must be replaced.

One method to selectively separate the RE chlorides from the salt is oxygen sparging to convert these species to oxides or oxychlorides that precipitate from the salt melt [6]. Converting $\mathrm{RECl}_{3}$ into $\mathrm{REOCl}$ and $\mathrm{REOCl}$ to $\mathrm{RE}_{2} \mathrm{O}_{3}$ in the presence of oxide ions proceeds according to the following reactions:

$$
\begin{gathered}
\mathrm{RECl}_{3}+\mathrm{O}^{2-} \rightarrow \mathrm{REOCl}+2 \mathrm{Cl}^{-}(\mathrm{g})(1) \\
2 \mathrm{REOCl}+\mathrm{O}^{2-} \rightarrow \mathrm{RE}_{2} \mathrm{O}_{3}+2 \mathrm{Cl}^{-}(\mathrm{g})(2)
\end{gathered}
$$

According to the literature [6-9], full conversion of the REs to oxides in the $\mathrm{LiCl}-\mathrm{KCl}$ eutectic salt melt is difficult. According to Cho et al. [7] and Hayashi and Minato [8], some $\mathrm{RE}^{3+}$ cations tend to remain in the form of stable oxychlorides. Katayama et al. [9] and Suh et al. [10,11] reported that the stability of $\mathrm{RE}_{2} \mathrm{O}_{3}$ and $\mathrm{REOCl}$, while related to the oxide-ion activity $\left(p \mathrm{O}^{2-}\right)$, is higher for some REs (e.g., $\mathrm{Ln}^{3+}$ ) than for others (e.g., $\mathrm{Gd}^{3+}$ ).

Provided that a pure stream of RE oxides can be generated, a borosilicate glass is a desirable waste form from a standpoint of waste loading potential and chemical durability [12,13]. 


\subsection{Rare earth oxides in borosilicate glasses}

Borosilicate glass has been selected for HLW immobilization because it 1) has a high tolerance for the chemical complexity of the wastes, 2) has excellent chemical durability, 3) melts easily, and can accommodate high waste loadings $[14,15]$. In this work, we compare three types of borosilicate glasses all of which have been established as possible candidates for the vitrification of nuclear wastes. Our focus is to compare their crystallization behavior, in particular the liquidus temperature $\left(T_{\mathrm{L}}\right)$ and the equilibrium crystallinity below the $T_{\mathrm{L}}$. These three types of borosilicate glasses are the International Simple Glass (ISG) designed by the International Working Group, sodium borosilicate glass developed by Korea Hydro and Nuclear Power, and the lanthanide aluminoborosilicate (LABS) glass established in the United States.

The ISG was designed as a reference benchmark HLW glass for dissolution studies [16]. Various versions of ISG with lower boron content were used for structural studies [14,15,17]. Their glasses can accommodate up to 30 mass $\%$ of waste loadings and can be processed at 1300 to $1400^{\circ} \mathrm{C}$. Glasses containing $\mathrm{SiO}_{2}, \mathrm{~B}_{2} \mathrm{O}_{3}, \mathrm{Na}_{2} \mathrm{O}$, and $\mathrm{Li}_{2} \mathrm{O}$, formulated by Korea Hydro and Nuclear Power in feasibility studies of lanthanide waste [18], accommodated 20 to 40 mass $\%$ of waste oxides when melted at 1200 to $1300^{\circ} \mathrm{C}$. Finally, $\mathrm{LABS}$ glass with $\mathrm{SiO}_{2}: \mathrm{B}_{2} \mathrm{O}_{3}: \mathrm{Al}_{2} \mathrm{O}_{3}$ in the ratio 3:1:2 by mass, respectively, allowed the RE loadings of up to 62 mass \% when melted at 1300 to $1450^{\circ} \mathrm{C}[12,13,19,20]$.

In Korea, the cold crucible induction melter (CCIM) was designed by the Nuclear Environment Technology Institute to vitrify low- and intermediate- level radioactive waste [21]. Unlike jouleheated melters for which the operating temperature is limited to $1150^{\circ} \mathrm{C}$, the CCIM can be operated at temperatures up to $1700^{\circ} \mathrm{C}$. This high temperature capability allows for processing of nuclear waste glasses with high liquidus temperatures $\left(T_{\mathrm{L}}\right)$. The CCIM may be a viable option for some of the glasses processed in this study.

Glasses with high waste loading can potentially contain a large fraction of components that form crystalline phases [22]. Crystallization can be problematic if large, high-density crystals precipitate and settle in the melter [22]. In the demonstration test of the CCIM at Savannah River National Laboratory for vitrification of a simulated HLW, researchers concluded that crystal settling might interfere with, and potentially obstruct, the bottom discharge valve of the melter [21]. In addition, RE oxides have a strong tendency to form crystalline phases in glass melts [23] depending on the type, size, and quantity of the crystal [17]. Fortunately, small crystals and crystals with densities close to that of the melt settle slowly and can be completely removed from the melter to the canister.

While in the canister, crystals continue to grow during cooling. Generally, RE-containing glasses possess high chemical durability [18-20,23-25]. However, if the crystalline phases remove important 
glass network components from the matrix glass, crystallization can compromise the chemical durability of the residual glass.

Rare earth oxides, such as $\mathrm{Gd}_{2} \mathrm{O}_{3}$ and $\mathrm{La}_{2} \mathrm{O}_{3}$, were proposed as nonradioactive surrogates for actinides to immobilize actinide-bearing radioactive wastes. According to $\mathrm{Li}$ et al. [23], changing the $\mathrm{Na}_{2} \mathrm{O} /\left(\mathrm{Al}_{2} \mathrm{O}_{3}+\mathrm{Na}_{2} \mathrm{O}\right)$ ratio in the baseline glass composition will effects $\mathrm{REs}$ solution behavior in the glass. Zhao et al. [24] made a high-durability borosilicate glass-ceramic containing Gd as a surrogate for actinides that formed a cation-oxyapatite crystalline phase.

Rare earth silicates precipitate from glasses in various morphologies, such as needle-, plate-, and rod-like crystals [19]. Quintas et al. [14-17], Ahn et al. [26], and Crum et al. [27-28] detected crystals with an apatite structure, such as oxyapatite or more specifically $\mathrm{Ca}_{2} \mathrm{RE}_{8} \mathrm{Si}_{6} \mathrm{O}_{26}$, which formed during thermal treatment of the glasses. Quintas et al. [14] determined that a small fraction of $\mathrm{Ca}_{2+x} \mathrm{Nd}_{8}$ ${ }_{x}\left(\mathrm{SiO}_{4}\right)_{6} \mathrm{O}_{2-0.5 x}(x=0.14$ to 0.41$)$ phase formed in a complex waste glass with a significant amount of $\mathrm{CaO}$ and $\mathrm{RE}_{2} \mathrm{O}_{3}$. Peeler et al. [19] reported RE silicates found as $\mathrm{RE}_{3} \mathrm{BSi}_{2} \mathrm{O}_{10}$ crystals in LABS-Sr glass.

Quintas et al. [17] showed that lanthanides beyond Eu have a low crystallization tendency and argued that RE elements with smaller ionic radii (e.g., $\mathrm{Ce}=101 \mathrm{pm}, \mathrm{Pr}=99 \mathrm{pm}, \mathrm{Nd}=98.3 \mathrm{pm}$ ) tend to crystallize, whereas La (103.2 pm) has a slight tendency to form crystals even though it has a small ionic radius [29]. Also, $\mathrm{RE}$ ions with ionic radii close to $\mathrm{Ca}^{2+}$ (100 pm), such as $\mathrm{Pr}$ and $\mathrm{Nd}$, are likely to be present in the apatite crystalline phase. Bondar [30] and Crum et al. [28] were able to substitute $\mathrm{Y}_{2} \mathrm{O}_{3}$ and a wide variety of $\mathrm{RE}_{2} \mathrm{O}_{3}$ into the oxyapatite structure.

\subsection{Solubility of rare earth oxides and liquidus temperature}

Suppose a single RE oxide is added in an increasing fraction of glass of a given composition at a given temperature until a crystalline phase begins to precipitate at equilibrium. The corresponding RE oxide fraction represents its solubility and the corresponding temperature is the $T_{\mathrm{L}}$ of the glass in which the RE oxide is at the solubility limit. Solubility of a RE is a function of glass composition and temperature. As Caurant et al. [32] demonstrated, the solubility of RE cations depends on their valence states where RE(IV) are less soluble than RE(III). Kim and Lee [18] formulated an $\mathrm{SiO}_{2}-$ $\mathrm{B}_{2} \mathrm{O}_{3}-\mathrm{Na}_{2} \mathrm{O}-\mathrm{Li}_{2} \mathrm{O}-\mathrm{RE}(\mathrm{III})_{2} \mathrm{O}_{3} / \mathrm{RE}(\mathrm{IV}) \mathrm{O}_{2}$ glass where $\mathrm{RE}(\mathrm{III})=\mathrm{Nd}, \mathrm{La}, \mathrm{Eu}, \mathrm{Gd}, \mathrm{Sm}, \mathrm{Y}$ and $\mathrm{RE}(\mathrm{IV})$ $=\mathrm{Ce}, \operatorname{Pr}$. For these glasses, $T_{\mathrm{L}}$ is $<950^{\circ} \mathrm{C}$ even when the RE fraction was as high as 20 mass $\% \mathrm{RE}$ oxides.

The major focus of this study was to collect information about the formation of crystalline phases from glasses containing high fractions of RE oxides. This preliminary research compares three different glass compositions for feasibility of immobilizing rare earth oxide waste streams from 
pyroprocessing. In this work, the product consistency test (PCT) was performed for selected crystalfree glasses to compare the three types of compositions tested. No attempt was made at this stage to determine the impact of crystallization in these glasses on their chemical durability. The crystallinity of glasses produced in the melter and poured into the canister are unlikely to reach equilibrium crystallinity because the rate of crystallization is generally not rapid enough.

\section{Experimental Methods}

Two experimental steps were performed for this study: 1) glass fabrication and 2) heat treatment of glass samples to determine liquidus temperatures [33]. The techniques used were optical microscopy, scanning electron microscopy with energy dispersive spectroscopy (SEM-EDS), and Xray diffraction (XRD) with whole pattern fitting. Chemical durability was assessed using the PCT [35] as an indicator for the waste form acceptability. The experimental steps and the analytical techniques are described below.

\subsection{Glass fabrication}

The 250-g batches of ISG glasses (FL and FR), candidate glasses (CG), and LABS glass (see Table 1) were made from fine powders of oxides $\left(\mathrm{SiO}_{2}, \mathrm{ZrO}_{2}, \mathrm{Al}_{2} \mathrm{O}_{3}, \mathrm{La}_{2} \mathrm{O}_{3}, \mathrm{CeO}_{2}, \mathrm{Nd}_{2} \mathrm{O}_{3}, \mathrm{Eu}_{2} \mathrm{O}_{3}\right.$, $\mathrm{Gd}_{2} \mathrm{O}_{3}, \mathrm{Pr}_{6} \mathrm{O}_{11}, \mathrm{Sm}_{2} \mathrm{O}_{3}$, and $\left.\mathrm{Y}_{2} \mathrm{O}_{3}\right)$, carbonates $\left(\mathrm{Na}_{2} \mathrm{CO}_{3}, \mathrm{CaCO}_{3}\right.$, and $\left.\mathrm{Li}_{2} \mathrm{CO}_{3}\right)$, and boric acid. The batches were homogenized in an agate vibratory mill for $4 \mathrm{~min}$. Batches were melted in a covered $\mathrm{Pt} / 10 \% \mathrm{Rh}$ crucible at $1300^{\circ} \mathrm{C}$ for $1 \mathrm{~h}$ except the LABS glass, which was melted at $1325^{\circ} \mathrm{C}$ (Table 1 ). The melts were poured on an Inconel ${ }^{\circledR}$ plate to air quench. The cooled glasses were ground in a tungsten carbide mill for $4 \mathrm{~min}$, remelted for $1 \mathrm{~h}$, and then quenched under the same conditions. Glass melting temperatures were purposely selected within the range of 1300 to $1400^{\circ} \mathrm{C}$ to facilitate processing. All glasses were observed through the optical microscope for any phase separation or crystallization before testing. The ISG and CG glasses were homogeneous and transparent, while the LABS glass appeared transparent in transmitted light and had a dark auburn color. No attempt was made to measure the glass compositions after melting because all of the glasses were batched using analytical grade chemicals and melted in covered Pt crucibles. In addition, very little volatility was observed suggesting no preferential loss of volatile components during melting.

Four ISG-based glasses were prepared. Two contained only $\mathrm{La}_{2} \mathrm{O}_{3}$ as a typical RE element (FL glasses) and the other two (FR glasses) contained the full spectrum of anticipated pyroprocessing RE composition (in mass\%) $38.45 \mathrm{Nd}_{2} \mathrm{O}_{3}-23.76 \mathrm{CeO}_{2}-11.62 \mathrm{La}_{2} \mathrm{O}_{3}-11.14 \mathrm{PrO}_{2}-7.68 \mathrm{Sm}_{2} \mathrm{O}_{3}-4.86$ $\mathrm{Y}_{2} \mathrm{O}_{3}-1.46 \mathrm{Eu}_{2} \mathrm{O}_{3}-1.02 \mathrm{Gd}_{2} \mathrm{O}_{3}$. The two FL glasses were prepared to compare with FR glasses by representing only one RE oxide in the waste composition. We tested two levels of waste loading: 10 and 15 mass $\%$. 
In addition, two borosilicate compositions (designated CG glasses in Table 1) were prepared based on a study by Kim and Lee [18], who recommended them for their high waste loading and low $T_{\mathrm{L}}$. Glasses fabricated with 20 and 25 mass $\%$ waste, consisting of a mixture of 38.20 mass $\% \mathrm{Nd}_{2} \mathrm{O}_{3}$, and 61.80 mass $\% \mathrm{CeO}_{2}$ normalized to the ratio of original composition in the waste spectrum were melted at $1300^{\circ} \mathrm{C}$. Finally, a LABS glass was made with 53 mass $\%$ of the $38.20 \mathrm{Nd}_{2} \mathrm{O}_{3}-61.80 \mathrm{CeO}_{2}$ (in mass\%) mixture (the same as CG glasses). In these CG and LABS glasses, the waste composition was represented by $\mathrm{Nd}_{2} \mathrm{O}_{3}$ and $\mathrm{CeO}_{2}$ because of their high composition in the anticipated pyroprocessing waste.

\subsection{Liquidus temperature}

The $T_{\mathrm{L}}$ of each glass was measured following ASTM C1720-11, specifically, the crystal fraction extrapolation method $[33,34]$. The glass was crushed and sieved to the particle size recommended in the procedure, between $0.422 \mathrm{~mm}$ and $4 \mathrm{~mm}(+40 /-5 \mathrm{mesh})$. The sieved glasses were ultrasonically washed three times in a clean glass beaker using deionized water. The glass particles then were submerged in ethanol and ultrasonically cleaned three times. After decanting the ethanol, the samples were dried in an open glass beaker at $\geq 90^{\circ} \mathrm{C}$ for $\geq 1 \mathrm{~h}$ in an oven. The glasses were retrieved and stored in clean containers prior to use.

The furnace for heat treatment was calibrated using glass of known $T_{\mathrm{L}}$ (SRM-773) to determine the uncertainty of the thermocouple and furnace used during the test. All glass samples were heat treated in a covered $1.2-\mathrm{cm}^{3} \mathrm{Pt} / 10 \% \mathrm{Rh}$ crucible at temperatures from $850^{\circ} \mathrm{C}$ to $1150^{\circ} \mathrm{C}$ in increments of $50^{\circ} \mathrm{C}$, or less if necessary. The samples were heat treated for $24 \pm 2 \mathrm{~h}$ at temperatures $>900^{\circ} \mathrm{C}$ and for up to $48 \pm 4 \mathrm{~h}$ at temperatures $<900^{\circ} \mathrm{C}$.

After each heat treatment, the samples were air quenched and divided into two portions for analysis. One portion was crushed for XRD analysis in a tungsten carbide mill to a fine powder with a known amount of $\mathrm{CaF}_{2}$ as an internal standard.

\subsection{X-ray diffraction}

The powdered samples were doped with 5 mass $\% \mathrm{CaF}_{2}$ and analyzed with XRD using a Bruker ${ }^{\circledR}$ D8 Advance (Bruker AXS Inc., Madison, WI) XRD with $\mathrm{Cu} \mathrm{K}_{\alpha}$ emission and a LynxEye ${ }^{\mathrm{TM}}$ positionsensitive detector with a collection window of $3^{\circ} 2 \theta$. Scan parameters were 5 to $70^{\circ} 2 \theta$ with a step of $0.015^{\circ} 2 \theta$ and a 0.3 -s dwell at each step. Crystalline phase identification was done with DIFFRAC ${ }^{\text {plus }}$ EVA (Bruker AXS). Further analysis was done using TOPAS 4.2 (Bruker AXS) whole pattern fitting software. The added $\mathrm{CaF}_{2}$ functioned as an internal standard for quantification of the other crystalline phases in the sample. Once the crystal fractions were determined, the $T_{\mathrm{L}}$ was calculated using the ASTM C1720-11 procedure [33,34]. 


\subsection{Microscopy}

The other portion of the $T_{\mathrm{L}}$ sample was selected for optical microscopy and SEM-EDS to determine crystal morphology and chemical composition. Optical microscopy was performed with an Olympus SZH10 (Waltham, MA). The SEM-EDS analysis was conducted with a JSM-7001F fieldemission gun microscope (JEOL USA, Inc. Peabody, MA) coupled with a Bruker xFlash 6|60 EDS detector. The samples were prepared in thin sections with specimens $\sim 0.25 \mathrm{~mm}$ thick. The thin sections were polished to a $1-\mu \mathrm{m}$ finish.

\subsection{Chemical durability study}

The samples for durability testing were prepared and measured using the PCT designated as ASTM C1285-14 [35]. Based on the procedure, the glasses were sieved to the particle size of $-100 /+200$ mesh (i.e., 74 to $149 \mu \mathrm{m}$ ). The glasses were crushed in a tungsten carbide vibratory mill and sieved to achieve the recommended size. The sieved glasses were ultrasonically washed with deionized water three times. Then, the deionized water was replaced with absolute ethanol, and the material was washed again three times. The samples were then dried in the oven overnight at $90 \pm 10^{\circ} \mathrm{C}$. The glasses were retrieved and placed into Teflon vessels filled with deionized water for a recommended ratio volume of solution to mass of solid ( $\left.V_{\text {soln }} / m_{\text {solid }}\right)$ of $10 \pm 0.5 \mathrm{~mL}$. Each glass was tested by PCT in duplicate. Blanks also were prepared with deionized water at a leachant volume similar to that of the sample. All samples and blanks were placed together in a forced air convection oven at $90 \pm 2^{\circ} \mathrm{C}$ for $7 \mathrm{~d}$.

After the 7-d leaching period, the samples were retrieved and cooled to room temperature. The leachates were removed from the vessels, $\mathrm{pH}$ was measured and recorded, and remaining solutions were filtered with a $0.45-\mu \mathrm{m}$ syringe filter and stored in a clean container. Nitric acid (1\% from the leachate volume) was spiked into the filtered leachate prior to analysis to prevent possible hydrolysis of heavy cations. The solutions were analyzed using inductively coupled plasma-optical emission spectroscopy for glass components and inductively coupled plasma-mass spectroscopy was used for RE components. Normalized releases of elements were then calculated using ASTM C1285-14 [35].

\section{Results and Discussions}

\subsection{Liquidus temperature}

We obtained the $T_{\mathrm{L}}$ as an intercept of the trendline fitted to crystal fraction data (obtained by XRD and the TOPAS refinement software) against heat treatment temperature as shown in Fig. 1. For FL10 and FL15 glasses, the $T_{\mathrm{L}}$ values were $966^{\circ} \mathrm{C}$ and $1052^{\circ} \mathrm{C}$, respectively, and $970^{\circ} \mathrm{C}$ and $1052^{\circ} \mathrm{C}$ for FR10 and FR15 glasses, respectively. Two outliers were omitted because they clearly did not agree with the other points from FL10 at $849^{\circ}$ and $904^{\circ} \mathrm{C}$, and outliers at $880^{\circ} \mathrm{C}$ and $904^{\circ} \mathrm{C}$ were omitted in 
FL15 and FR15 plots. At equal waste loadings, $T_{\mathrm{L}}$ values of FL and FR were close to each other with relative standard deviations of $0.26 \%$ and $0.02 \%$ for 10 and 15 mass $\%$ waste loadings, respectively. This indicates the $\mathrm{La}_{2} \mathrm{O}_{3}$ alone can represent the full spectrum of $\mathrm{RE}$ components when it comes to the crystallinity.

Previous studies showed that $\mathrm{B}(\mathrm{IV}) / \mathrm{B}(\mathrm{III})$ ratio decreased with increasing $\mathrm{RE}$ ionic radius and increasing Ln concentration in the glass composition [15,17]. However, the boron content in the glass composition in those studies was two times lower than those used in this study. In slow-cooled, lowboron glasses, a La-containing glass had a lower crystallization tendency than in glasses containing $\mathrm{RE}$ with smaller ionic radii than Eu [17]. This may explain the tendency of boron to form $\mathrm{LaBSiO}_{5}$ (detected as $\mathrm{CeBSiO}_{5}$ ) in $\mathrm{FL}$ glasses while staying in glass network in FR glasses containing mixed REs. Fig. 2 shows XRD diagrams of crystalline phases detected in the samples.

In spite of having similar $T_{\mathrm{L}}$ values, the FL and FR glasses formed different primary crystalline phases distinguished by XRD (see Fig. 2); FL glasses precipitated $\mathrm{LaBSiO}_{5}$ crystals, which were detected as $\mathrm{CeBSiO}_{5}$ (FL glasses contained $\mathrm{La}_{2} \mathrm{O}_{3}$ as a single lanthanide) and $\mathrm{FR}$ glasses precipitated oxyapatite in the form of $\mathrm{Ca}_{2} \mathrm{RE}_{8} \mathrm{Si}_{6} \mathrm{O}_{26}$. Fig. 3 shows a micrograph of a 15 mass\% waste-loaded FR glass with needle-like crystals and hexagonal platelets with a central hole, which probably is a tiny bubble on which the crystal nucleated. Oxyapatite can likely accommodate any RE element [14,17,26-28] and even $\mathrm{Na}$ and $\mathrm{Li}$ [17], or Na, Sr and Cs [28]; however, Kim and Lee [18] did not find any $\mathrm{Li}$ in $\mathrm{Nd}$-silicate crystals that precipitated from a Li-containing borosilicate glass. Boron substitution in the Si sites in the apatite structure was reported by Quintas et al. [17], Ahn et al. [26], and Crum et al. [28].

Kim and Lee [18] selected two candidate glasses with high waste loadings that were crystal-free at $\sim 1300^{\circ} \mathrm{C}$. We reproduced their compositions except we used only two major RE components, $\mathrm{CeO}_{2}$ and $\mathrm{Nd}_{2} \mathrm{O}_{3}$ (designated CG glasses in Table 1) in lieu of their full RE mix. Fig. 1 shows crystallinity in $\mathrm{CG}$ glasses as function of temperature with data fitted by linear trendlines, omitting outliers at $1042^{\circ} \mathrm{C}$ and $1075^{\circ} \mathrm{C}$ due to inconsistencies with other points. $\mathrm{XRD}$ analysis identified $\mathrm{CeO}_{2}$ in $\mathrm{CG}$ glasses as showed in Fig. 2, pictured by SEM in Fig. 4 from heat-treated sample of CG20 at $999^{\circ} \mathrm{C}$ for $23.8 \mathrm{~h}$. From EDS results, we determined that the cubic crystals contained $>70$ mass $\% \mathrm{CeO}_{2}$. The crystals also contained $\sim 4$ mass $\% \mathrm{Nd}_{2} \mathrm{O}_{3}$ and large fractions of $\mathrm{Na}_{2} \mathrm{O}$ and $\mathrm{SiO}_{2}$, probably from the surrounding glass matrix.

The $T_{\mathrm{L}}$ values were $1080^{\circ} \mathrm{C}$ and $1118^{\circ} \mathrm{C}$ for CG20 and CG25, respectively. In contrast, Kim and Lee [18] reported $T_{\mathrm{L}}<950^{\circ} \mathrm{C}$ in the glass containing the full spectrum of RE with the primary phase of Nd-silicate. Even though glasses in the present work contained a mixture of only two REs oxides, $\mathrm{Nd}_{2} \mathrm{O}_{3}$ and $\mathrm{CeO}_{2}$, one would expect that the oxide with a higher oxidation state, $\mathrm{CeO}_{2}$, would 
precipitate preferably to that of a lower oxidation state, $\mathrm{Nd}_{2} \mathrm{O}_{3}$, which would remain dissolved. As Kim and Lee [18] admit, their melts were probably affected by the material dissolved from clay crucibles in which they made the glasses (they switched to using Pt crucibles for heat treatments).

For the LABS glass, the heat treatment was carried out in duplicate. Fig. 1 shows the primary crystalline fraction in the LABS glass as a function of temperature, yielding $T_{\mathrm{L}}=1201^{\circ} \mathrm{C}$. Fractions of crystalline phases detected by XRD are summarized in Table 2 and the distinguished peaks are shown in Fig. 2. The uncertainties of $T_{\mathrm{L}}$ results were contributed from furnace error bars of $\pm 3^{\circ} \mathrm{C}$ and \pm 0.005 for crystal fraction extrapolation (added to Fig. 1) to account for estimated errors associated with the technique. Unlike ISG and CG glasses, LABS glass produced four kinds of crystalline phases during heat treatment.

Fig. 5 shows the crystal morphology in the LABS glass heat-treated at $999^{\circ} \mathrm{C}$ for $23.7 \mathrm{~h}$. The primary crystalline phase, the light gray crystals in the figure, are Ce-borosilicate $\left[\mathrm{Ce}_{3}\left(\mathrm{BSiO}_{6}\right)\left(\mathrm{SiO}_{4}\right)\right]$, the same as reported for LABS glass containing Sr [19]. The other three crystalline phases observed were small white cubic crystals of $\mathrm{CeO}_{2}$ that occasionally formed chains, black crystals of mullite $\left(\mathrm{Al}_{5} \mathrm{SiO}_{9.5}\right)$, and corundum $\left(\mathrm{Al}_{2} \mathrm{O}_{3}\right)$ crystals. This glass showed higher tendency of $\mathrm{Ce}^{3+}$ than $\mathrm{Ce}^{4+}$ crystallization, probably enhanced and substituted by $\mathrm{Nd}^{3+}$ in crystal structure due to similar ionic radii.

Even though boron content was low in this glass, it had a tendency to precipitate the primary crystalline phase with a low oxidation $\mathrm{Ce}^{3+}$. The high oxidation $\mathrm{Ce}^{4+}$ probably crystallized as $\mathrm{CeO}_{2}$ during cooling after the heat treatment because the crystal fractions were present in all samples regardless of the heat treatment temperatures in a range of 1.41 to 1.95 mass\%. Crum et al. [28] also observed $\mathrm{CeO}_{2}$ crystals with $\mathrm{ZrO}_{2}$ in the glass-ceramic for mixed waste. The mullite fraction seems to follow a primary phase trend. No mullite was detected above $1097^{\circ} \mathrm{C}$, whereas corundum formed above $1147^{\circ} \mathrm{C}$ (at $1147^{\circ} \mathrm{C}$, corundum only appeared in one of the duplicates).

The $T_{\mathrm{L}}$ may limit the waste loading in glass. Suppose we compare FL15 or FR15 with CG25 and LABS glasses, the latter glass shows a higher $T_{\mathrm{L}}$. The lower $T_{\mathrm{L}}$ of CG glass is caused by a high content of alkalis and the higher $T_{\mathrm{L}}$ of alkali-free LABS glass is associated with its high content of REs.

\subsection{Product consistency tests}

Table 3 summarizes the normalized elemental releases (in $\mathrm{g} / \mathrm{m}^{2}$ ) of glass components from quenched crystal-free samples. Uncertainties were calculated based on the averages from duplicate samples. Releases of B and Na from ISG and LABS glasses were far lower $\left(0.03\right.$ to $0.46 \mathrm{~g} / \mathrm{m}^{2}$ and 0.47 to $0.53 \mathrm{~g} / \mathrm{m}^{2}$, respectively) than those from the standard environmental-assessment glass (5.36 to 
8.35 and 4.28 to $7.61 \mathrm{~g} / \mathrm{m}^{2}$ for B and Na, respectively) [12,13,19], the CG glasses (36.91 to 46.71

$\mathrm{g} / \mathrm{m}^{2}$ and 30.42 to $40.10 \mathrm{~g} / \mathrm{m}^{2}$ for B and $\mathrm{Na}$, respectively), and the glass-ceramic waste form (27.8 and $23.7 \mathrm{~g} / \mathrm{m}^{2}$ for B and Na, respectively) reported by Kim and Heo [31]. As Table 3 shows, the PCT normalized releases of CG glasses were even higher than those from environmental-assessment glass. This finding is consistent with the extremely high $\mathrm{Na}_{2} \mathrm{O}$ content in these glasses that is not compensated by the charge-balancing $\mathrm{Al}_{2} \mathrm{O}_{3}$ [36]. On the other hand, the PCT B, Si, and $\mathrm{Al}$ releases from the LABS glass were within the range of previous studies $\left(0.003\right.$ to $0.041 \mathrm{~B} \mathrm{~g} / \mathrm{m}^{2}, 0.002$ to 0.013 Si $\mathrm{g} / \mathrm{m}^{2}$, and 0 to $\left.0.013 \mathrm{Al} \mathrm{g} / \mathrm{m}^{2}\right)[12,13,19]$.

All glasses show extremely low releases of RE components as shown in Table 3: 10 $0^{-4} \mathrm{~g} / \mathrm{m}^{2}$ from ISG and LABS glasses and $\sim 10^{-3} \mathrm{~g} / \mathrm{m}^{2}$ from CG glass. The detection limit was less than 0.25 and 0.24 $\mu \mathrm{g} / \mathrm{L}$ for Ce and Nd, respectively, in the solution. The FL15 and FR15 glasses exhibited similar results for all components even though the FL15 only had one RE component $\left(\mathrm{La}_{2} \mathrm{O}_{3}\right)$.

\section{Conclusion}

Three different glass types (ISG, alkali-borosilicate glass, and LABS glass) designed to immobilize lanthanide waste from used-fuel pyroprocessing were tested for crystallinity and chemical durability. Differences in the $T_{\mathrm{L}}$ and PCT between ISG glasses with the full set of RE components (FR glasses) and with only $\mathrm{La}_{2} \mathrm{O}_{3}$ (FL glasses) appeared insignificant. The durability of the alkaliborosilicate glass containing over 23 mass $\% \mathrm{Na}_{2} \mathrm{O}$ was found to be insufficient. The LABS glass had the highest $T_{\mathrm{L}}\left(1201^{\circ} \mathrm{C}\right)$ and waste loading $(53$ mass $\%)$ and exhibited superior durability.

\section{Acknowledgement}

The authors would like to thank B. R. Johnson and other staff members of Pacific Northwest National Laboratory (PNNL). This work at PNNL was supported by the U.S. Department of Energy (DOE) Waste Treatment and Immobilization Plant Federal Project Office under the direction of A. A. Kruger. PNNL is operated by Battelle for DOE under Contract Number DE-AC05-76RL01830. The authors would like to acknowledge Jong Heo and the Division of Advanced Nuclear Engineering for supporting this work by the BK21+ program through the National Research Foundation of Korea funded by the Ministry of Education, Science and Technology.

\section{References}

[1] Radioactive Waste Management Programmes in OECD/NEA Member Countries - Korea. 2013. (Online). Accessed July 28, 2013 at https://www.oecdnea.org/rwm/profiles/Korea_profile_web.pdf. 
[2] H. Lee, J.-M. Hur, J.-G. Kim, D.-H. Ahn, Y.-Z. Cho, S.-W. Paek, Energy Procedia 7 (2011) $391-395$.

[3] H. Lee, G.-I. Park, K.-H. Kang, J.-M. Hur, J.-G. Kim, D.-H. Ahn, Y.-Z. Cho, E. H. Kim, Nucl. Eng. Technol. 43 (2011) 317-328.

[4] J.-H. Yoo, C.-S. Seo, E.-H. Kim, H.-S. Lee, Nucl. Eng. Technol. 40 (2008) 581-592.

[5] H.-S. Park, I.-H. Cho, H.C. Eun, I.-T. Kim, Y.Z. Cho, H.-S. Lee, Environ. Sci. Technol. 45 (2011) 1932-1939.

[6] Y.-Z. Cho, H.-C. Yang, G.-H. Park, H.-S. Lee, I.-T. Kim, J. Nucl. Mater. 384 (3) (2009) 256-261.

[7] Y.-J. Cho, H.-C. Yang, H.-C. Eun, E.-H. Kim, I.-T. Kim, J. Nucl. Sci. Technol. 43 (10) (2006) $1280-1286$.

[8] H. Hayashi, K. Minato, J. Phys. Chem. Sol. 66 (2-4) (2005) 422-426.

[9] Y. Katayama, R. Hagiwara, Y. Ito, J. Electrochem. Soc. 142 (7) (1995) 2174-2178.

[10] G.W. Suh, Y.H. Paik, J. Korean Inst. Metals Mater. 30 (1992) 438.

[11] G.W. Suh, Y.H. Paik, J. Korean Inst. Metals Mater. 30 (1992) 981.

[12] A.L. Youchak-Billings, J.V. Crum, J.C. Marra, B.J. Riley, J.D. Vienna, A. Edmondson. 2008. Waste/Storage Form Baseline-Fission Products \& Lanthanides. GNEP-WAST-PMO-MI-DV2008-000151, Savannah River National Laboratory, Aiken, SC.

[13] J.V. Crum, A.L. Billings, J. Lang, J.C. Marra, C. Rodriguez, J.V. Ryan, J.D. Vienna. 2009. Baseline Glass Development for Combined Fission Products Waste Streams. AFCI-WASTWAST-MI-DV-2009-000075, Pacific Northwest National Laboratory, PNNL-18524, Richland, WA.

[14] A. Quintas, D. Caurant, O. Majérus, T. Charpentier, J.-L. Dussossoy, Mater. Res. Bull. 44 (2009) 1895-1898.

[15] I. Bardez, D. Caurant, J.L. Dussossoy, P. Loiseau, C. Gervais, F. Ribot, D.R. Neuville, N. Baffier, C. Fillet. Structural characterization of rare-earth-rich glasses for nuclear waste immobilization. In the Proc. of ATALANTE 2004 (Advances for future nuclear fuel cycles), Nimes, France, 2008. 
[16] S. Gin, A. Abdelouas, L.J. Criscenti, W.L. Ebert, K. Ferrand, T. Geisler, M.T. Harrison, Y. Inagaki, S. Mitsui, K.T. Mueller, J.C. Marra, C.G. Pantano, E.M. Pierce, J.V. Ryan, J.M. Schofield, C.I. Steefel, J.D. Vienna, Mater. Today 16 (2013) 243-248.

[17] A. Quintas, D. Caurant, O. Majérus, J.L. Dussossoy, T. Charpentier. Effect of changing the rare earth cation type on the structure and crystallization behavior of an aluminoborosilicate glass. In the Proc. of the XXI ${ }^{\text {st }}$ International Congress on Glass (ICG 2007), Strasbourg, France, 2007.

[18] C.W. Kim, B.G. Lee, J. Korean Radioact. Waste Soc. 11 (2013) 1-9.

[19] D. Peeler, T.B. Edwards, I.A. Reamer, J.D. Vienna, D.E. Smith, M.J. Schweiger, B.J. Riley, J.V. Crum. Composition/property relationships for the Phase $1 \mathrm{Am} / \mathrm{Cm}$ glass variability study, WSRC-TR-99-00055, Rev. 0, Savannah River Site, Aiken, South Carolina, 1999.

[20] J.-H. Choi, I.-H. Cho, H.-C. Eun, H.-S. Park, Y.-Z. Cho, K.-R. Lee, G.I. Park, S.-H. Kim, C.-H. Shin, J.-K. Kim, J. Radioanal. Nucl. Chem. 299 (2014) 1731-1738.

[21] M.E. Smith, A.B. Barnes, A.S. Choi, J.C. Marra. NETEC cold crucible induction melter demonstration for SRNL with simulated Sludge Batch 4 DWPF waste. In A. Cozzi \& T. Ohji (Eds.), Environmental Issues and Waste Management Technologies in the Materials and Nuclear Industries XII. New Jersey: John Wiley \& Sons, Inc, 2009, pp. 29-37.

[22] P. Hrma, B.J. Riley, J.V. Crum, J. Matyas, J. Non-Cryst. Solids 384 (2014) 32-40.

[23] L. Li, D.M. Strachan, H. Li, L.L. Davis, M. Qian, J. Non-Cryst. Solids 272 (2000) 46-56.

[24] D. Zhao, L. Li, L.L. Davis, W.J. Weber, R.C. Ewing. Gadolinium borosilicate glass-bonded Gdsilicate apatite: a glass-ceramic nuclear waste form for actinides. In the Proc. of the Mater. Res. Soc. 663, K.P. Hart and G.R. Lumpkin (eds.), 2000.

[25] M. Wang, M. Li, J. Cheng, F. He, Z. Liu, Y. Hu, J. Nucl. Mater. 433 (2013) 287-296.

[26] B.G. Ahn, H.S. Park, I.T. Kim, Y. J. Cho, H. S. Lee, Energy Procedia 7 (2011) 529-533.

[27] J.V. Crum, L.A. Turo, B.J. Riley, M. Tang, A. Kossoy, J. Am. Ceram. Soc. 95 (2012) 1297-1303.

[28] J. Crum, V. Maio, J. McCloy, C. Scott, B. Riley, B. Benefiel, J. Vienna, K. Archibald, C. Rodriguez, V. Rutledge, Z. Zhu, J. Ryan, M. Olszta, J. Nucl. Mater. 444 (2014) 481-492.

[29] R.D. Shannon, Acta Cryst. A32 (1976) 751-767.

[30] I.A. Bondar, Ceram. Int. 8 (1982) 83-89. 
[31] M. Kim, J. Heo. Ceram. Int. 41 (4) (2015) 6132-6136.

[32] D. Caurant, P. Loiseau, O. Majérus, V. Aubin-Chevaldonnet, I. Bardez, A. Quintas. Glasses, Glass-ceramics and ceramics for immobilization of highly radioactive nuclear wastes. Nova Science Publishers, Inc., 2009.

[33] ASTM C1720-11, Standard Test Method for Determining Liquidus Temperature of Immobilized Waste Glasses and Simulated Waste Glasses, ASTM Int., West Conshohocken, PA, 2011.

[34] B.J. Riley, P.R. Hrma, J.D. Vienna, M.J. Schweiger, C.P. Rodriguez, J.V. Crum, J.B. Lang, J.C. Marra, F.C. Johnson, D.K. Peeler, C. Leonelli, A.M. Ferrari, I. Lancellotti, J.-L. Dussossoy, R.J. Hand, J.M. Schofield, A.J. Connelly, R. Short, M.T. Harrison, Int. J. Appl. Glass Sci. 2 (4) (2011) 321-333.

[35] ASTM C-1285-14, Standard Test Methods for Determining Chemical Durability of Nuclear, Hazardous and Mixed Waste Glasses and Multiphase Glass Ceramics: the Product Consistency Test (PCT), ASTM Int. West Conshohocken, PA, 2008.

[36] G.F. Piepel, S.K. Cooley, I. Muller, H. Gan, I. Joseph, I.L. Pegg, ILAW PCT, VHT, Viscosity, and Electrical Conductivity Model Development, VSL-07R1230-1, The Catholic University of America, Washington, DC. 


\section{Figure Captions:}

Fig. 1. Crystal fraction as a function of temperature for FL, FR, CG, and LABS glasses.

Measurements were made in duplicate. Error bars on points are $\pm 3^{\circ} \mathrm{C}$ for temperature and \pm 0.005 for the crystal fraction.

Fig. 2. XRD diagram of each crystalline phase

Fig. 3. Morphology of oxyapatite $\left[\mathrm{Ca}_{2} \mathrm{RE}_{8} \mathrm{Si}_{6} \mathrm{O}_{26}\right]$ crystals in heat-treated $\mathrm{FR}$ glass (FR15 at $980^{\circ} \mathrm{C}$ for $25.6 \mathrm{~h})$

Fig. 3. Morphology of $\mathrm{CeO}_{2}$ crystal in heat-treated $\mathrm{CG}$ glasses $\left(\mathrm{CG} 20\right.$ at $999^{\circ} \mathrm{C}$ for $23.8 \mathrm{~h}$ )

Fig. 4. Morphology of all crystals in heat-treated LABS glass $\left(999^{\circ} \mathrm{C}\right.$ for $\left.23.7 \mathrm{~h}\right)$

\section{Table Captions:}

Table 1. Glass melting temperatures $\left(T_{\mathrm{M}}\right)$, compositions (in mass fraction), and waste loading

Table 2. Fraction of crystalline phases in LABS glass by XRD in mass fractions

Table 3. Summary of 7-day PCT normalized releases $\left(\mathrm{g} / \mathrm{m}^{2}\right)$ from crystal-free glasses 


\section{Figures and Tables}

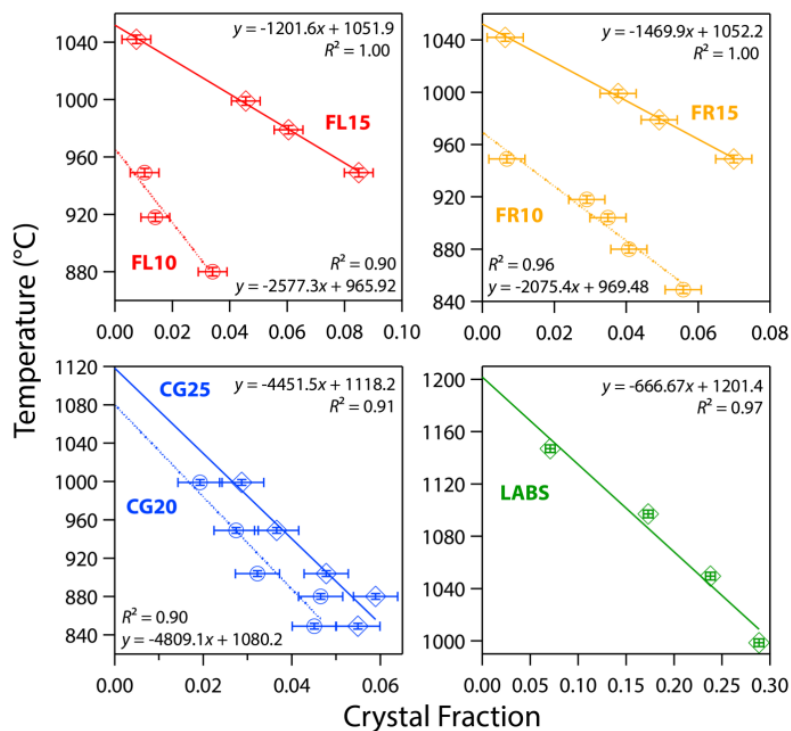

Fig. 1. Crystal fraction as function of temperature for FL, FR, CG, and LABS glasses. Measurements were made in duplicate. Error bars on points are $\pm 3^{\circ} \mathrm{C}$ for temperature and \pm 0.005 for the crystal fraction. 


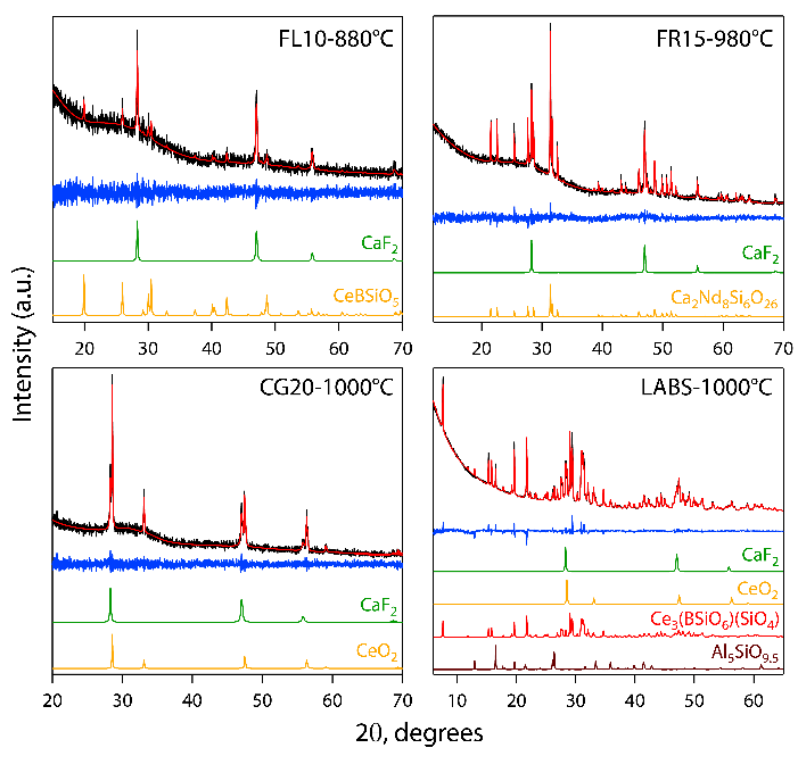

Fig. 2. XRD diagram of each crystalline phase 


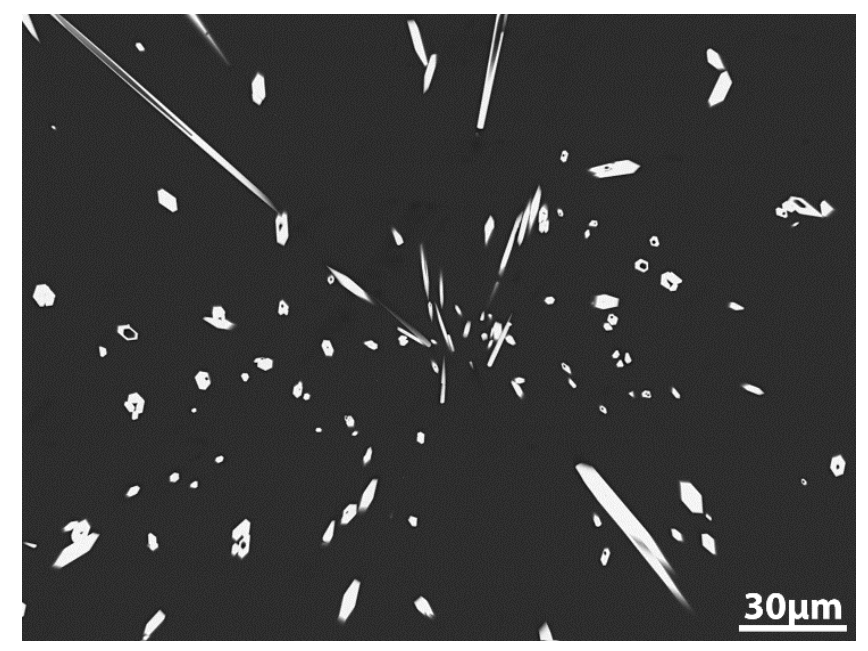

Fig. 3. Morphology of oxyapatite $\left[\mathrm{Ca}_{2} \mathrm{RE}_{8} \mathrm{Si}_{6} \mathrm{O}_{26}\right]$ crystals in heat-treated FR glass (FR15 at $980^{\circ} \mathrm{C}$ for $25.6 \mathrm{~h}$ ) 


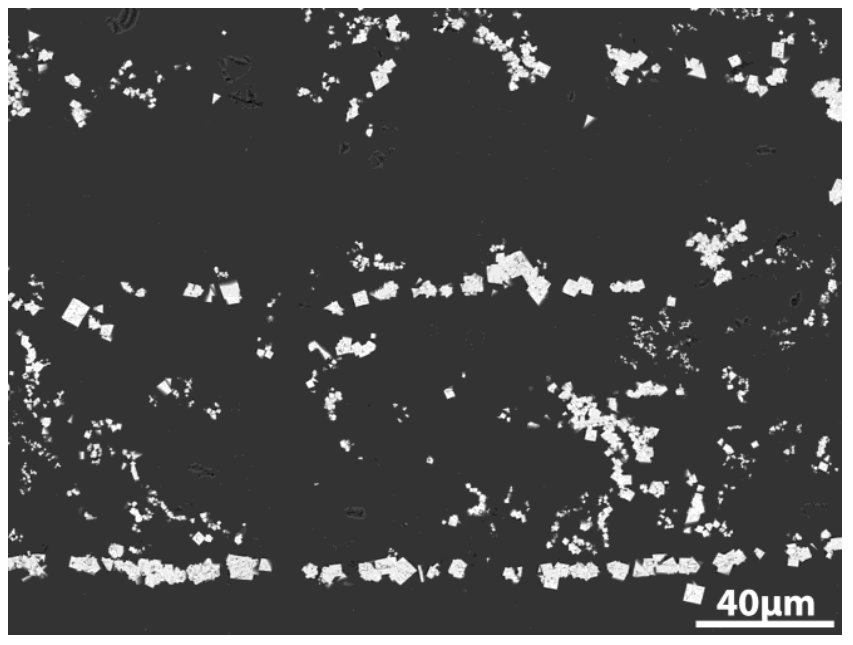

Fig. 4. Morphology of $\mathrm{CeO}_{2}$ crystal in heat-treated $\mathrm{CG}$ glasses $\left(\mathrm{CG} 20\right.$ at $999^{\circ} \mathrm{C}$ for $23.8 \mathrm{~h}$ ) 


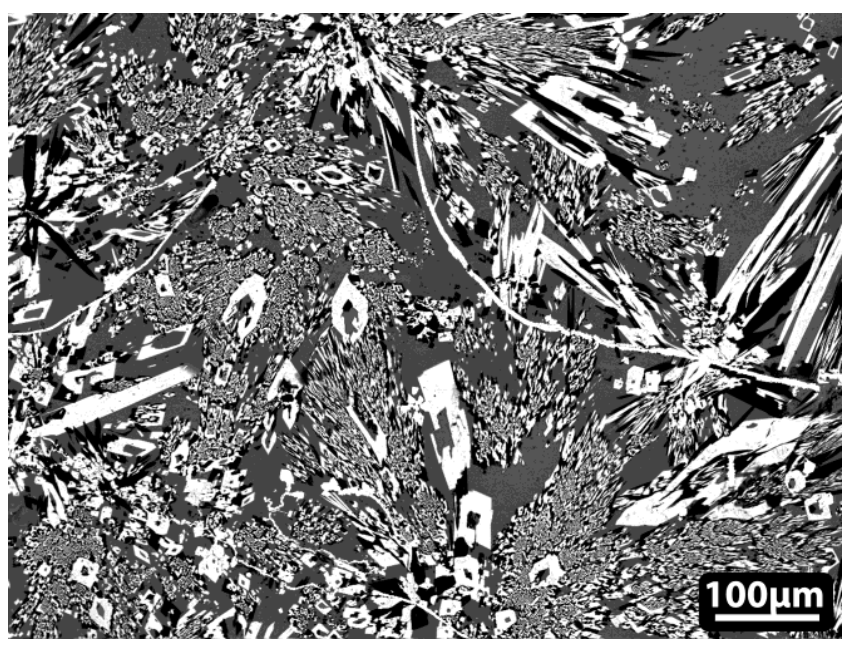

Fig. 5. Morphology of all crystals in heat-treated LABS glass $\left(999^{\circ} \mathrm{C}\right.$ for $\left.23.7 \mathrm{~h}\right)$ 
Table 1. Glass melting temperatures $\left(T_{\mathrm{M}}\right)$, compositions (in mass fraction), and waste loading

\begin{tabular}{lccccccc}
\hline Oxides & FL10 & FL15 & FR10 & FR15 & CG20 & CG25 & LABS \\
\hline$T_{\mathrm{M}}\left({ }^{\circ} \mathrm{C}\right)$ & 1300 & 1300 & 1300 & 1300 & 1300 & 1300 & 1325 \\
\hline $\mathrm{Al}_{2} \mathrm{O}_{3}$ & 0.0542 & 0.0512 & 0.0542 & 0.0512 & - & - & 0.1930 \\
$\mathrm{~B}_{2} \mathrm{O}_{3}$ & 0.1560 & 0.1473 & 0.1560 & 0.1473 & 0.1143 & 0.1071 & 0.0797 \\
$\mathrm{CaO}$ & 0.0448 & 0.0423 & 0.0448 & 0.0423 & - & - & - \\
$\mathrm{Li} 2 \mathrm{O}$ & - & - & - & - & 0.0343 & 0.0321 & - \\
$\mathrm{Na}_{2} \mathrm{O}$ & 0.1093 & 0.1033 & 0.1093 & 0.1033 & 0.2514 & 0.2357 & - \\
$\mathrm{SiO}_{2}$ & 0.5064 & 0.4782 & 0.5064 & 0.4783 & 0.4000 & 0.3751 & 0.1973 \\
$\mathrm{ZrO}_{2}$ & 0.0293 & 0.0277 & 0.0293 & 0.0277 & - & - & - \\
$\mathrm{CeO}_{2}$ & - & - & 0.0238 & 0.0357 & 0.0764 & 0.0955 & 0.2024 \\
$\mathrm{Eu}_{2} \mathrm{O}_{3}$ & - & - & 0.0015 & 0.0022 & - & - & - \\
$\mathrm{Gd}_{2} \mathrm{O}_{3}$ & - & - & 0.0010 & 0.0015 & - & - & - \\
$\mathrm{La}_{2} \mathrm{O}_{3}$ & 0.1000 & 0.1500 & 0.0116 & 0.0174 & - & - & - \\
$\mathrm{Nd}_{2} \mathrm{O}_{3}$ & - & - & 0.0384 & 0.0577 & 0.1236 & 0.1545 & 0.3276 \\
$\mathrm{PrO}_{2}$ & - & - & 0.0111 & 0.0167 & - & - & - \\
$\mathrm{Sm}_{2} \mathrm{O}_{3}$ & - & - & 0.0077 & 0.0115 & - & - & - \\
$\mathrm{Y}_{2} \mathrm{O}_{3}$ & - & - & 0.0049 & 0.0073 & - & - & - \\
\hline $\mathrm{Sum}$ & 1.0000 & 1.0000 & 1.0000 & 1.0000 & 1.0000 & 1.0000 & 1.0000 \\
\hline $\mathrm{Waste} \mathrm{loading}$ (mass\%) & 10 & 15 & 10 & 15 & 20 & 25 & 53 \\
\hline
\end{tabular}


Table 2. Fraction of crystalline phases in LABS glass by XRD in mass fractions

\begin{tabular}{lcccc}
\hline Temp $\left({ }^{\circ} \mathrm{C}\right)$ & $\mathrm{CeO}_{2}$ & Ce-borosilicate & Mullite & Corundum \\
\hline 999 & 0.0179 & 0.2887 & 0.1633 & - \\
1050 & 0.0187 & 0.2380 & 0.1241 & - \\
1097 & 0.0184 & 0.1730 & 0.1027 & - \\
1147 & 0.0190 & 0.0709 & - & 0.0130 \\
1202 & 0.0143 & - & - & 0.0229 \\
\hline
\end{tabular}


Table 3. Summary of 7-day PCT normalized releases $\left(\mathrm{g} / \mathrm{m}^{2}\right)$ from crystal-free glasses

\begin{tabular}{cccccc}
\hline Element/Glass & FL15 & FR15 & CG20 & CG25 & LABS \\
\hline $\mathrm{B}$ & $0.46 \pm 0.02$ & $0.42 \pm 0.06$ & $46.71 \pm 0.43$ & $36.91 \pm 0.11$ & $0.03 \pm 0.002$ \\
$\mathrm{Si}$ & $0.16 \pm 0.001$ & $0.14 \pm 0.03$ & $19.67 \pm 0.44$ & $10.53 \pm 0.007$ & $0.01 \pm 0.001$ \\
$\mathrm{Al}$ & $4.9 \pm 0.3 \times 10^{-3}$ & $5.8 \pm 1.1 \times 10^{-3}$ & - & - & $0.3 \pm 0.4$ \\
$\mathrm{Ca}$ & $0.04 \pm 0.002$ & $0.03 \pm 0.004$ & - & - & - \\
$\mathrm{Li}$ & - & - & $27.72 \pm 0.02$ & $20.25 \pm 0.2$ & - \\
$\mathrm{Na}$ & $0.53 \pm 0.001$ & $0.47 \pm 0.07$ & $40.10 \pm 1.13$ & $30.42 \pm 0.90$ & - \\
$\mathrm{Ce}$ & - & $\mathrm{ND}$ & $1.6 \pm 0.7 \times 10^{-3}$ & $3.2 \pm 0.3 \times 10^{-4}$ & $1.9 \pm 1.3 \times 10^{-5}$ \\
$\mathrm{Nd}$ & - & $\mathrm{ND}$ & $1.9 \pm 2.2 \times 10^{-3}$ & $1.9 \pm 0.6 \times 10^{-3}$ & $1.3 \pm 0.4 \times 10^{-4}$ \\
$\mathrm{La}$ & $6.0 \pm 0.9 \times 10^{-5}$ & $6.3 \pm 2.3 \times 10^{-5}$ & - & - & - \\
$\mathrm{Eu}$ & - & $8.8 \pm 3.2 \times 10^{-5}$ & - & - & - \\
$\mathrm{Pr}$ & - & $8.3 \pm 3.0 \times 10^{-5}$ & - & - & - \\
$\mathrm{Sm}$ & - & $9.0 \pm 3.5 \times 10^{-5}$ & - & - & - \\
$\mathrm{Y}$ & - & $8.2 \pm 2.9 \times 10^{-5}$ & - & - & \\
\hline
\end{tabular}

ND: The value was below limit of detection. 